4. Tihomirov Yu. A. Organizaciya i provedenie pravovogo monitoringa / Yu. A. Tihomirov // Pravo i ekonomika. 2006. - № 10. - S. 11-15.

5. Tolmacheva N. N. O nekotoryh problemah obespecheniya effektivnosti zakonodatel'nogo regulirovaniya ekonomicheskih preobrazovanij / N. N. Tolmacheva // Zhurnal rossijskogo prava. - 2006. - № 10. - S. 78-84.

\title{
Павлюков І. І. Застосування правових засобів при здійсненні правового моніторингу
}

Автором статті пропонується визначення правового моніторингу та його класифікація. Розкривається значення правового моніторингу як адміністративно-правового засобу забезпечення законності у правотворчій діяльності органів державної влади. Аналізуються проблеми юридичної техніки правового моніторингу: визначаються техніко-юридичні компоненти механізму реалізації аналітичної функції, з'ясовано завдання, що виникають в процесі реалізації аналітичної функції правового моніторингу та методи їх вирішення.

Ключові слова: правовий моніторинг, функції правового моніторингу, правові засоби правового моніторингу, критерії та показники оцінки ефективності законодавства, методи правового моніторингу.

\section{Pavlyukov I. I. Application of legal measures in implementation of legal monitoring}

The author of this article proposes the definition of legal monitoring and its classification. The significance of legal monitoring as an administrative and legal means of ensuring legality in law-making activity of state authorities is revealed. The problems of the legal technique of legal monitoring are analyzed: the technical and legal components of the mechanism for the implementation of the analytical function are identified, the problems arising in the implementation of the analytical function of legal monitoring and the methods for their solution are identified.).

Key words: legal monitoring, functions of legal monitoring, legal means of legal monitoring, criteria and indicators for assessing the effectiveness of legislation, methods of legal monitoring.

DOI: 10.33.66.3/2524-017X-2019-10-223-226

Удк 340

\author{
Наталія Олегівна Палій, \\ аспірантка відділу теорії держави і права \\ Інституту держави і права ім. В. М. Кореиьького НАН Украӥни
}

\section{ГЕНДЕРНА ПРАВОВА ЕКСПЕРТИЗА. СУЧАСНІ ВИКЛИКИ ТА ЗАВДАННЯ}

Постановка проблеми - в сучасній науці та практиці існує проблема розробки теоретичних та методологічних засад здійснення гендерно-правової експертизи, особливо в частині ефективності проведення такої експертизи. На даний час законодавство розрізняє гендерно-правову експертизу чинного законодавства та гендерно-правову експертизу проектів нормативно-правових актів. Водночас, слід звернути увагу на те, що деякі норми мають виключно декларативний характер, тому наукова складова має вкрай важливе значення для практичної реалізації встановлених законодавством норм.

Не можна не погодитись 3 твердженнями А. С. Олійник щодо важливості вивчення даного питання.

Гендерна експертиза Конституції України та конституційного законодавства свідчить, що конституційний принцип рівності прав і можливостей жінки і чоловіка де-юре визнано і закріплено, а де-факто він повсюдно порушується. На тлі соціально-економічних проблем Української держави проблема гендерної рівності не стала пріоритетним напрямком внутрішньої політики України, а отже, ще не можна вести серйозну мову про повне втілення міжнародних стандартів [1, с. 74].

Дослідження актуальності методології здійснення гендерно-правової експертизи допоможе удосконалити існуючі механізми проведення гендерно-правової експертизи. Наукові напрацювання в даній сфері мають практичну реалізацію та покликані покращити механізм практичної реалізації принципу рівності чоловіків та жінок. 
Аналіз останніх досліджень та публікацій. Дослідженню процедури правової експертизи нормативно-правових актів, однією зі складових якої є гендерно-правова експертиза, присвятили свої праці В. О. Бутенко, Т. О. Дідич, П. С. Корнієнко, Н. М. Пархоменко, О. О. Разуваєв, О. М. Шишпаренок, Н. В. Філик, Г. В. Рибікова та інші. Крім того, питання саме гендерно-правової експертизи досліджували такі науковці як Т. М. Мельник, К. Б. Левченко, Н. Б. Болотіна, 3. В. Ромовська, А. С. Олійник, В. Буроменський та інші.

Протягом 1999-2000 років в рамках Програми рівних можливостей Програми розвитку ООН в Україні науковцями та представниками громадських організацій була здійснена гендерна експертиза окремих галузей українського законодавства: трудового, міжнародного, конституційного, соціального тощо.

Погоджуємось із думкою Н. Б. Болотіної про застосування у якості концептуального підходу до гендерної експертизи законодавства категорії прав людини «саме такий підхід дає змогу: визначити зміст гендерного принципу у законотворенні та на стадії правозастосування; на основі проведеного таким чином аналізу законодавства, сформувати пропозиції щодо його удосконалення та практики застосування з метою забезпечення гендерного паритету» [2, с. 13].

Можна погодитись 3 твердженням 3. В. Ромовської у дослідженні «Сімейне законодавство України. Гендерна експертиза», яка звертає увагу на важливість застосування гендерної експертизи в сфері сімейного права [3, с. 5].

Не можна не зауважити відсутність принципового ставлення до визначення часу проведення такої експертизи. Те саме можна зауважити і щодо дослідження Н. Б. Болотіної та А. С. Олійник.

А. С. Олійник у своїй праці «Конституційне законодавство України. Гендерна експертиза» відзначає важливість наукових досліджень в сфері гендерно-правової експертизи законодавства.

«У конституційний розвиток України, встановлення гарантій забезпечення рівних можливостей жінок і чоловіків щодо реалізації їх конституційних прав значний внесок повинна зробити юридична наука. Об'єктом її особливої уваги має стати зміст та складові принципу гендерної рівності, механізм його реалізації та забезпечення, вдосконалення гендерних аспектів права. 3 теоретичних позицій юридична наука повинна визначати загальну стратегію і пріоритетні напрями законодавчої діяльності щодо забезпечення рівних прав і свобод жінки і чоловіка, створення рівних можливостей їх реалізації відповідно до Конституції України та міжнародних зобов'язань України» $[1$, с. 6].

T. М. Мельник вважає, що гендерна експертиза законодавства $є$ одним із елементів гуманізації суспільствотворення та державотворення, визначення критеріїв їх оптимальності та демократичності [4, с. 18].

М. В. Буроменський, досліджуючи питання гендерної експертизи в площині міжнародного права, дійшов до наступних висновків.

«У XXI ст. світ увійшов з ідеєю і практикою оптимізації гендерного компонента в усіх сфеpax життя. На це спрямовано вироблення гендерних стандартів, принципів та напрямів діяльності. Вони зумовлені світовими процесами глобалізації, демократизації, гуманізації соціального життя, важливою складовою яких є соціально-статеві відносини. Вивчення і аналіз міжнародного законодавства, його гендерного конструкту та міжнародного досвіду гендерної діяльності розширює національний світогляд щодо вироблення механізмів впровадження міжнародних норм та нормотворення в українському законодавстві з гендерної проблематики» [5, с. 39].

Отже, аналіз основної літератури з питань гендерної політики дає підставу вважати, що ставиться, по суті, і вивчається законодавство про гендерну рівність, а отже, і необхідність проведення гендерно-правової експертизи, але не вивчається методологія і своєчастність проведення такої експертизи.

Метою статті $\epsilon$ аналіз теоретичних та методологічних засад здійснення та ефективності проведення гендерно-правової експертизи.

3 метою дослідження даного питання варто з'ясувати таке: проаналізувати дефініцію гендерноправової експертизи, визначити мету проведення гендерно-правової експертизи, проаналізувати ефективність проведення гендерно-правової експертизи, запропонувати можливі шляхи удосконалення гендерно-правової експертизи.

Виклад основного матеріалу. Гендерно-правова експертиза проводиться відповідно до статті 4 Закону України «Про забезпечення рівних прав та можливостей жінок і чоловіків» від 8 вересня 2005 року № 2866-IV [6] та постанови Кабінету Міністрів України від 28 листопада 2018 року № 997 «Питання проведення гендерно-правової експертизи» [7]. 
Наказом Міністерства юстиції України від 27 листопада 2018 року №3719/5 затверджено Методичні рекомендації 3 проведення гендерно-правової експертизи актів законодавства та проектів нормативно-правових актів [8].

Для проведення аналізу ефективності реалізації тих чи інших норм права необхідно розглянути понятійний апарат. В першу чергу, слід звернути увагу на дефініцію «гендерна експертиза». Т. М. Мельник дає визначення гендерної експертизи як «міжнародно-правовий підхід до оцінки чинного законодавства 3 позицій свободи, справедливості та рівностей статей» $[4$, с. 10$]$.

У Законі України «Про забезпечення рівних прав та можливостей жінок і чоловіків» гендерно-правова експертиза - це аналіз чинного законодавства, проектів нормативно-правових актів, результатом якого $є$ надання висновку щодо їх відповідності принципу забезпечення рівних прав та можливостей жінок і чоловіків [6].

Чинне законодавство, на відміну від твердження окремих науковців, встановлює необхідність аналізу не лише чинного законодавства, а й проектів нормативно-правових актів.

Відповідно до Методичних рекомендацій з проведення гендерно-правової експертизи актів законодавства та проектів нормативно-правових актів гендерно-правова експертиза полягає у проведенні критичної оцінки (аналізу) того, яким чином різниця в гендерних ролях, діяльності, потребах, можливостях та правах впливає на жінок, чоловіків, дівчат та хлопчиків, в існуючій або запропонованій політиці, ситуації або контексті, та формуванні пропозицій з усунення дискримінаційних положень.

Проведення гендерно-правової експертизи в усіх сферах законодавства має на меті формування гендерно-чутливого законодавства для досягнення кінцевої мети - досягнення рівності прав та можливостей жінок та чоловіків [8].

Відповідно до Порядку проведення гендерно-правової експертизи метою проведення гендерно-правової експертизи є: проведення комплексного дослідження законодавства та проектів нормативно-правових актів у частині їх відповідності міжнародним договорам України, згода на обов'язковість яких надана Верховною Радою України, та резолюціям міжнародних конференцій, міжнародних організацій, їх органів 3 прав людини стосовно дотримання принципу забезпечення рівних прав та можливостей жінок і чоловіків; та запобігання прийняттю та наявності нормативно-правових актів, положення яких не відповідають принципу забезпечення рівних прав та можливостей жінок і чоловіків [7].

Водночас чинне законодавство не встановлює необхідності запобігання прийняття законів, положення яких не відповідають принципу гендерної рівності, як і відповідальності за порушення цієї вимоги.

Гендерно-правова експертиза проектів нормативно-правових актів проводиться розробником проектів нормативно-правових актів та Міністерством юстиції України під час проведення правової експертизи. Гендерно-правова експертиза вже чинного законодавства (а саме законів України, актів Президента України, Кабінету Міністрів України та інших нормативно-правових актів) проводиться Міністерством юстиції України. Гендерно-правова експертиза законодавства проводиться щороку до 31 грудня згідно із планом, що затверджується уповноваженою особою (координатором) 3 питань забезпечення рівних прав та можливостей жінок і чоловіків Мін'юсту.

Йдеться про чинне законодавство. Проте слід відмітити, що законопроекти, які подаються до Верховної Ради депутатами не проходять перевірку ні Міністерства юстиції ні іншого органу на предмет відповідності дотримання принципу забезпечення рівних прав та можливостей жінок і чоловіків. Фактично не відбувається запобігання появи в законодавстві дискримінаційних норм на етапі підготовки та обговорення законопроекту. Безперечно, недопущення наявності норм, які порушують права певних категорій осіб, є ефективнішим способом захисту прав та свобод, ніж перевірка законодавства після його прийняття.

Крім того, потрібно констатувати факт, що на даний час відсутня ефективна процедура виправлення недоліків в разі виявлення дискримінаційних норм у законодавстві.

Висновок про результати гендерно-правової експертизи законодавства протягом п'яти календарних днів після підписання уповноваженою особою (координатором) з питань забезпечення рівних прав та можливостей жінок і чоловіків Мін'юсту оприлюднюється на офіційному веб-сайті Мін'юсту.

У разі встановлення невідповідності акта законодавства принципу забезпечення рівних прав та можливостей жінок і чоловіків Мін'юст надсилає висновок з обгрунтованими зауваженнями органові, що прийняв такий акт. 
Копія такого висновку також надсилається Мінсоцполітики та Кабінетові Міністрів України.

Мінсоцполітики протягом 30 календарних днів 3 дати отримання висновку за результатами його розгляду визначає доцільність внесення змін та ініціює перед Кабінетом Міністрів України таке завдання відповідному центральному органові виконавчої влади відповідно до вимог Регламенту Кабінету Міністрів України, затвердженого постановою Кабінету Міністрів України від 18 липня 2007 р. № 950 (Офіційний вісник України, 2007 р., № 54, ст. 2180; 2011 р., № 88, ст. 3199) [7].

Таким чином, можна зробити висновок, що процедура виправлення недоліків у законодавстві внаслідок встановлення невідповідності акта законодавства принципу забезпечення рівних прав та можливостей жінок і чоловіків є тривалою та не завжди ефективною. Вбачається логічним виправлення недоліків на етапі створення законопроекту, особливо враховуючи той факт, що закони в ієрархії мають вищу юридичну силу в порівнянні 3 постановами Кабінету Міністрів України, нормативно-правовими актами міністерств та відомств.

Методичні рекомендації з проведення гендерно-правової експертизи актів законодавства та проектів нормативно-правових актів зобов'язують враховувати, що законодавство України - утворена на ієрархічній основі система нормативно-правових актів, тому рекомендується спочатку проводити гендерно-правову експертизу тих актів законодавства у відповідній сфері, що мають вищу юридичну силу, а потім переходити до актів нижчої юридичної сили [8].

Проте на практиці може виникнути ситуація коли здійснюється аналіз нормативно-правового акта, яких регулює відносини в цій же сфері, що і закон, стосовно якого гендерно-правова експертиза ще не була проведена, а тільки запланована.

Враховуючи вищевикладене, слід звернути увагу на законодавчу ініціативу, а саме Проект Закону України «Про внесення змін до деяких законодавчих актів України щодо гендерно-правової експертизи» від 20 квітня 2018 року № 8315, внесений народними депутатами Сусловою I. М., Луценко І. С., Заліщук С. П., Лещенко С. А., Костанкевич І. М., Агафоновою Н. В., Королевською Н. Ю., Ричковою Т. Б., Романовою А. А., Сотник О. С., Шкрум А. І. [9].

Абсолютно обгрунтованою $є$ ініціатива щодо внесення законопроекту, метою якого є удосконалення існуючого механізму гендерно-правової експертизи законодавства та проектів нормативноправових актів задля попередження дискримінації за ознакою статі та дотримання принципу рівних прав та можливостей жінок і чоловіків.

Даним законопроектом пропонується доповнити статтю 4 Закону «Про забезпечення рівних прав та можливостей жінок і чоловіків», а саме викласти ії в наступній редакції:

«Порядок та методику проведення гендерно-правової експертизи чинного законодавства, проектів нормативно-правових актів, крім законопроектів, (504-2006-п) визначає Кабінет Міністрів України.

Порядок та методику проведення гендерно-правової експертизи законопроектів визначає Верховна Рада України.»

Законопроектом передбачається проведення гендерно-правової експертизи чинного законодавства, проектів нормативно-правових актів, крім законопроектів, Кабінетом Міністрів України, а обов'язок гендерно-правової експертизи законопроектів покладається на Верховну Раду України.

Пропонується включити до змісту пояснювальної записки, як одного із супровідних документів законопроекту, положення щодо обгрунтування його впливу на забезпечення рівних прав та можливостей жінок і чоловіків.

Таким чином, буде здійснюватися запобігання прийняттю законів, положення яких не відповідають принципу забезпечення рівних прав та можливостей жінок і чоловіків, що сприятиме досягненню гендерної рівності.

Слід розділити думку А. С. Олійник про те, що «від того, наскільки законодавець у своій діяльності враховуватиме гендерний компонент, залежить прогрес у подоланні гендерної дискримінації і встановлення гендерної демократії в Україні» [1, с. 7].

Окрім зазначеного, необхідно удосконалити механізм усунення дискримінаційних норм. Адже наявність негативного висновку Міністерства юстиції України не є гарантією неприйняття Кабінетом Міністрів України акта, який містить дискримінаційні норми.

«У світовій практиці існує декілька підходів до реалізації негативних висновків експертів за результатами експертизи:

1) організатор експертизи направляє копію висновку в органи, уповноважені здійснювати контроль за діяльністю органу, що має усунути недоліки об'єкта експертизи (експертний висновок 
направляється органом, який проводив експертизу, в орган державної влади, який прийняв цей акт, а копії експертного висновку - в органи, які є вищими щодо органу, який прийняв акт, також у спеціалізовані органи з питань правотворчості, в прокуратуру, а за необхідності - і у відповідні органи виконавчої влади, а також вирішується питання про доцільність підготовки проекту запиту до суду конституційної юрисдикції або до президента щодо призупинення дії такого нормативно-правового акта);

2) нормативно-правовий акт не може бути внесеним до відповідного реєстру на підставі висновку експертизи (якщо нормативно-правовий акт не отримав позитивного висновку експертизи, він повертається до суб'єкта право творчості та не набирає чинності;

3) у випадку невідповідності проекту нормативно-правового акта Конституції в експертному висновку зазначається про неможливість його візування» [10, с. 63].

Висновки. Проведений аналіз дає змогу сформувати наступні рекомендації.

Важливим є дотримання принципу ієрархії законодавчих актів та здійснення запобігання попадання в законодавчу базу дискримінаційних норм. Для цього є обов’язкове запровадження гендерної експертизи законопроектів.

Необхідність комплексної відповідальності та контролю з боку не лише представників Міністерства юстиції України, а й Верховної ради України та центральних органів виконавчої влади, які відповідають за реалізацією (впровадження) обраного закону та здійснення контролю (нагляду) за його виконання щодо недопущення дискримінації.

Залучення громадських організацій, науковців, організація круглих столів, робочих зустрічей як $з$ метою ефективної реалізації діючих норм законодавства, так і підготовки законопроектів та удосконалення проведення гендерно-правової експертизи.

Фіксація гендерної статистики задля розуміння динаміки і еволюції гендерних змін у праві, що дасть можливість правильно оцінювати розроблювані законодавчі акти.

Проведений аналіз показав необхідність проведення подальших досліджень та наукових розробок для підвищення ефективності та якості здійснюваної експертизи.

\section{Список використаних джерел}

1. Олійник А. С. Конституційне законодавство України. Гендерна експертиза. - К. : Логос, 2001. - 77 с.

2. Болотіна Н. Б. Соціальне законодавство України. Гендерна експертиза. Відп. ред. Т. М. Мельник. - К. : Логос, 2001. $-82 \mathrm{c}$.

3. Ромовська 3. В. Сімейне законодавство України. Гендерна експертиза / Відп. ред. Т. М.Мельник. - К. : Логос, 2001. $-40 \mathrm{c}$.

4. Гендерна експертиза українського законодавства (концептуальні засади) / Відп. ред. Т. М. Мельник. - К. : Логос, 2001. - 120 c.

5. Буроменський М. В. Міжнародне право. Гендерна експертиза / Відп. ред. Т. М. Мельник. - К. : Логос, $2001 .-40$ с.

6. Закон України «Про забезпечення рівних прав та можливостей жінок і чоловіків» від 8 вересня 2005 року № 2866-IV [Електронний ресурс]. - Режим доступу : https://zakon.rada.gov.ua/laws/show/2866-15

7. Постанова Кабінету Міністрів України від 28 листопада 2018 року №997 «Питання проведення гендерно-правової експертизи» [Електронний ресурс]. - Режим доступу : https://zakon.rada.gov.ua/laws/show/997-2018-п

8. Методичні рекомендації з проведення гендерно-правової експертизи актів законодавства та проектів нормативно-правових актів, затверджені наказом Міністерства юстиції України від 27 листопада 2018 року №3719/5.

9. Проект Закону «Про внесення змін до деяких законодавчих актів України щодо гендерно-правової експертизи» від 20 квітня 2018 року № 831 [Електронний ресурс]. - Режим доступу : http://w1.c1.rada.gov.ua/pls/zweb2/ webproc4_1?pf3511=63922

10. Філик H. $B$., Рибікова Г. В. Процедура проведенян правової експертизи нормативно-правових актів в Україні / Філик Н. В., Рибікова Г. В. // Юридичний вісник. - 2017. - № 2 (43).

\section{References}

1. Oliinyk A. S. Constitutional legislation of Ukraine. Gender expertise. - K. : Lohos, 2001. - 77 s.

2. Bolotina N. B. Social legislation of Ukraine. Gender expertise / T. M. Melnyk. - K. : Lohos, 2001. - $82 \mathrm{~s}$.

3. Romovska Z. V. Family law of Ukraine. Gender expertise / T.M.Melnyk. - K.: Lohos, 2001. - 40 s.

4. Gender examination of Ukrainian legislation (conceptual basis) / T. M. Melnyk. - K. : Lohos, 2001. $-120 \mathrm{~s}$.

5. Buromenskyi M. V. International law. Gender expertise / T. M. Melnyk. - K. : Lohos, 2001. - 40 s.

6. The Law of Ukraine «On ensuring equal rights and opportunities for women and men» of September 8, 2005 № 2866IV: https://zakon.rada.gov.ua/laws/show/2866-15 
7. Resolution of the Cabinet of Ministers of Ukraine dated November 28, 2018 No. 997 Issues of gender legal examination: https://zakon.rada.gov.ua/laws/show/997-2018-p

8. Methodical recommendations for conducting a gender legal examination of acts of legislation and draft legal acts, approved by the Order of the Ministry of Justice of Ukraine dated November 27, 2018, No. 3719/5.

9. Draft Law «On Amending Certain Legislative Acts of Ukraine on Gender Legal Expertise» dated 20 April 2018 No. 831/: http://w1.c1.rada.gov.ua/pls/zweb2/webproc4_1?pf3511=63922

10. Filyk N. V., Rybikova H. V. Procedure for conducting legal expert examination of normative legal acts in Ukraine / Filyk N. V., Rybikova H. V/ Yurydychnyi visnyk - 2017 № 2 (43)

\section{Палій Н. О. Гендерна правова експертиза. Сучасні виклики та завдання}

У статті розкриваються питання здійснення гендерно-правової експертизи законодавства та нормативно-правових актів. Метою дослідження $є$ аналіз теоретичних та методологічних засад здійснення та ефективності проведення такої експертизи. В процесі дослідження було проаналізовано дефініцію гендерно-правової експертизи, визначено мету проведення гендерно-правової експертизи, досліджено ефективність проведення гендерно-правової експертизи та запропоновано можливі шляхи ії удосконалення.

На даний час законодавство розрізняє гендерно-правову експертизу існуючого законодавства та гендерно-правову експертизу проектів нормативно-правових актів. Водночас, слід звернути увагу на те, що деякі норми мають виключно декларативний характер, тому наукова складова має вкрай важливе значення для практичної реалізації встановлених законодавством норм.

Практичне значення даної статті полягає у дослідження методології здійснення гендерно-правової експертизи. Такі знання допоможуть удосконалити існуючі механізми проведення гендерно-правової експертизи. Наукові напрацювання в даній сфері можуть бути використані для забезпечення гендерної рівності, внесення змін в існуючу законодавчу базу для створення рівних прав та можливостей для жінок і чоловіків.

Ключові слова: методологія, гендерно-правова експертиза, українське законодавство, гендерна рівність, правова експертиза.

\section{Paliy N. O. Gender legal expertise. Modern Challenges and Challenges}

This article highlights the issues of gender-sensitive legal examination of laws and regulations. The study purpose is the analysis of theoretical and methodological principles of such examination implementation and effectiveness. The study analyzed the definition of gender-sensitive legal examination, identified the purpose of the gender-sensitive legal examination, studied the effectiveness of the gender-sensitive legal examination and suggested the possible ways to improve the same.

Currently, the law distinguishes between the gender-sensitive legal examination of applicable laws and gender-sensitive legal examination of draft regulations. However, it should be noted that some norms are purely declarative by nature, so the scientific component is essential for the practical implementation of the legal norms.

According to the methodological recommendations on gender-sensitive legal examination of legislative acts and draft regulations, the gender-sensitive legal examination implies a critical assessment (analysis) of how the differences in gender roles, activities, needs, opportunities and rights affects the women, men, girls and boys in the existing or proposed policy, situation or context, as well as development pf proposals to eliminate the discriminatory provisions.

Still, the applicable laws do not stipulate the need to prevent the adoption of laws, the provisions of which do not correspond to the gender equality principle.

This article focused the legislative initiative, namely the Draft Law of Ukraine on Amendments to Some Legislative Acts of Ukraine Regarding the Gender-Sensitive Legal Examination dated April 20, 2018 No. 8315, the goal of which is to improve the existing pattern of the gender-sensitive legal examination of laws and draft regulations to prevent the genderbased discrimination and to comply with the principle of equal rights and opportunities for women and men.

The practical significance of this article is to study the methodology of the gender-sensitive legal examination implementation. Such knowledge will help improve the existing patterns of the gender-sensitive legal examination. Scientific developments in this area can be used to ensure the gender equality and to amend the current legal framework to establish the equal rights and opportunities for women and men.

Key words: methodology, gender legal expertise, Ukrainian legislation, gender equality, legal expertise.

DOI: 10.33.66.3/2524-017X-2019-10-226-231 